\title{
The Progressive Party of 1948
}

MARC J. EPSTEIN

A historian's interpretation of the past is influenced, no doubt, by current events, but ordinarily it is his subject matter-his very choice of a topic-that is most affected by the problems of his own lifetime. It is little wonder, then, that many historians in the fifties and sixties were preoccupied with Afro-American history, the era of Reconstruction, and race relations, for the black-white issue dominated the American consciousness as did no other issue in the period. But the Vietnam war and economic demands by the poorer segments of our society have now pushed American foreign policy and domestic welfare reform into the forefront of concern. Since these are but two of the many problems that grew directly out of American programs and policies that took shape during the Truman Presidency, it should not be surprising that historians have turned their attention to foreign and domestic policy in the years immediately following World War Two. ${ }^{1}$ It was during this period that many basic decisions were made that would guide the United States for a generation.

Unexpectedly, perhaps, many of these policy decisions turned out to be bipartisan, at least in the sense that little attempt was made to overturn or reverse them once the Republican Eisenhower administration came into power. It is difficult, if not impossible, however, to understand and evaluate these policy choices without exploring existing alternatives. In the case of the Truman period, it is necessary to go outside of the political mainstream to find such alternatives.

Only one major politician and one nationwide organization, excluding perhaps Senator Robert Taft and his followers, made any attempt to challenge prevailing American policies at home and abroad during the Truman administration. The politician was Henry Agard Wallace

1 For a bibliography that is just now becoming dated, see Richard S. Kirkendall, ed., The Truman Period as a Research Field (Columbia: University of Missouri Press, 1967). 
and the organization was the Progressive party of 1948. Whether Wallace and the Progressive party actually provided viable policy alternatives is a question that only further scholarship will decide. What can be said, for now, is that both they and their opponents believed that they were challenging American policies and in many instances providing alternatives.

Henry A. Wallace was Franklin Roosevelt's choice for Secretary of Agriculture in 1932 and Vice-President in 1940. ${ }^{2}$ Although Wallace was much criticized by the liberal-left community during the thirties for many of his farm policies (particularly the Department of Agriculture's treatment of the sharecropper problem in the South, and its decision to destroy farm products in a Depression world of cold and hunger), he excited liberal imaginations during the war with stirring speeches identifying American war aims. Wallace's role as a spokesman for America's democratic war aims made him the darling of the liberal-left by 1944. But he had also antagonized political pros in the Democratic party and had failed to develop a rapport with leading figures in the Senate, over which he presided as Vice-President. In a turn of events that is still muddled, Wallace was unceremoniously dumped from the ticket at the 1944 Democratic convention. ${ }^{3}$ After Roosevelt's re-election, however, the former Vice-President asked for and received the post of Secretary of Commerce. Wallace continued to hold this office after Roosevelt's death even as most of the former President's appointees (Henry Morgenthau, Jr. at Treasury, Harold Ickes at Interior, Francis Biddle at Justice and so on) retired or were removed from office. Wallace did not last long either.

Early in 1946 the last of the major Roosevelt appointees became severely disenchanted with American foreign policy and the course of Soviet-American relations. Wallace believed that the United States was not doing enough to accommodate the security needs of the

2 The best full-length biography of Wallace, Henry A. Wallace of Iowa: The Agrarian Years, 1910-1940 (Ames: Iowa State University Press, 1968) and Prophet in Politics: Henry A. Wallace and the War Years, 1940-1965 (Ames: Iowa State University Press, 1970) by Edward L. and Frederick H. Schapsmeier, is undistinguished. But for two perceptive articles that treat Wallace in the immediate post-war period, see Max Lerner, "Henry Wallace: A Portrait In Symbols," Actions and Passions (New York: Simon and Schuster, 1949), pp. 225-228, and William Harlan Hale, "What Makes Wallace Run," Harper's Magazine (March, 1948), pp. 211-248.

${ }^{3}$ For two views of this interesting episode and its background, see Curtis MacDougall, Gideon's Army (New York: Marzani and Munsell, 1965) vol. 1, ch. 1, and James M. Burns, Roosevelt: The Soldier of Freedom (New York: Harcourt, Brace and Jovanovich, 1970), ch. 17. 
Soviet Union; that we reserved rights for ourselves and our allies which we attempted to deny the Soviets; that, finally, both superpowers were stumbling toward a third world war neither could survive. Wallace's continuing criticism of American foreign policy finally resulted in a dramatic showdown in the autumn of 1946, and the Secretary of Commerce was forced to resign from the cabinet. Having done so, Wallace, a private citizen for the first time in over a decade, began a crusade to force a change in American policies. At this point the former Secretary of Commerce crossed paths with a nationwide organization that had also become extremely critical of the Truman administration and American foreign policy-the Progressive Citizens of America. PCA had been formed in December 1946 as the result of a merger between two liberal-left lobby groups. The National Citizens Political Action Committee (NCPAC) and the Independent Citizens Committee of the Arts, Sciences and Professions (ICCASP) were organized prior to the 1944 presidential election to serve as campaign committees for the Roosevelt-Truman ticket, but each chose not to disband following the election. The two political action groups, whose members included such well-known figures as sculptor Jo Davidson, former Interior Secretary Harold Ickes, Mrs. Gifford Pinchot, activist wife of the former Pennsylvania governor, and A. F. Whitney, president of the Brotherhood of Railroad Trainmen, dedicated their efforts to achieving what they conceived to be Rooseveltian programs and policies. In doing so, they generally supported the Truman administration until early autumn 1945. But as the year ended and 1946 wore on, they became more and more critical. Their merger seemed a natural step for two competing organizations whose outlook and program were much the same. After Wallace left the cabinet, he slowly became the national spokesman for the kinds of criticisms PCA was voicing. In late 1947 Wallace decided that he could force a change in American policies only by running for the Presidency outside the twoparty structure, and PCA decided that it should start moving toward the status of a third party. These decisions alienated most of the wellknown figures who supported or sympathized with the Wallace-PCA critique, but this fact did not deter Wallace or the third party advocates. ${ }^{4}$

4 The sympathetic editor of the Nation, Freda Kirchwey, wrote: "Mr. Wallace's broad criticism of the Truman administration was effective. Most Progressives, I believe, would agree with most of it. It is in the detailed application of his general remarks that differences arise-differences important enough to riddle his whole case for a third party." Freda Kirchwey, "Wallace: Prophet or Politician," Nation ( January 10, 1948), p. 30. 
Planning for the New Party, as it was sometimes called, continued through the spring and early summer of 1948. The founding convention took place in the third week of July in Philadelphia. It was an astonishing affair by all accounts. Its numbers were dominated, not by party professionals, but by plain people with little practical political experience. "The throng certainly was not affluent," wrote one observer. "It included hundreds who had hitch-hiked to the convention; scores who lived in tent-towns on the convention hall parking lot." 5 But politically and intellectually the convention was dominated by the same coterie of individuals that had inspired the third party in the first place: persons such as Calvin B. Baldwin, a former Wallace assistant in the Department of Agriculture; Albert A. Fitzgerald, president of the United Electrical Workers; Elmer Benson, a former Minnesota senator; and Lee Pressman, the general counsel of the CIO. There was little controversy in the convention. The party members were all leftists of a more or less liberal stripe who blended on their own left wing with communist sympathizers and on their right with establishment liberals and old time populists. They were prepared to work with anyone, including communists, as long as they were subordinate to and accepting of the New Party's policies and programs. Abused and ridiculed by the press and by the other parties, the Progressives nevertheless ran a vigorous nationwide campaign. The situation was inopportune for a new party, however, and Wallace and the Progressives were thoroughly trounced in the election that autumn. Both faded from the national scene in the years that followed.

The New Party stood for a traditional American reform agenda in most respects. They believed that they would put into effect what others only promised. Among their objectives were progressive taxation, federal aid to education, the end to all forms of Jim Crow, a women's rights amendment to the Constitution, government ownership of the power industry, national economic planning and wide expansion of the federal welfare system-social security, health and unemployment insurance. In the area of foreign affairs the Progressives pressed hard for meaningful negotiation between the Soviet Union and the United States directed toward bringing about a rapprochement between the two superpowers. They demanded that the United States accept as fact that the Soviet Union had a sphere of influence in Eastern Europe by virtue of its wartime victories; that the United States give up programs and policies that further divided Europe into two warring camps and threatened the Soviet Union-the Truman

5 Howard K. Smith, “The Wallace Party," Nation (August 7, 1948), p. 146. 
Doctrine, NATO (in 1949) and even the Marshall Plan. Finally, they pleaded for the United States to accept and support the revolutionary striving of former colonial nations. ${ }^{6}$

If the Wallacites' programs and third-party political activity sound strikingly contemporary, it is not by chance. Many of the issues of the immediate post-war period have come back to haunt us. It is not surprising, then, that twenty years later history seemed to repeat itself. A somewhat lackluster liberal (as Wallace had been considered before the war), Eugene McCarthy, ran for the Presidency with youngish "united front" style support, calling for changes in American foreign policy, particularly disengagement from a civil war not unlike that in Greece in the earlier period. The parallels, and differences, are fascinating, but are another subject.

Unfortunately for Wallace and the Progressive party, the body of water in which they chose to swim had crosscurrents that neither could survive. They called for a peaceful accommodation between the United States and the Soviet Union precisely at the moment when both powers had realized that national interest and ideology made a peaceful accommodation impossible. The "cold war" was simply a mutual acceptance of that realization by both sides. Each consolidated its own sphere of influence and generally took care not to interfere overtly in the sphere of the other. (The problem was the fringes-the Middle East and Asia, for example.) At the same time, the Progressive party stood for "united front" political tactics at the very moment when most liberals had decided to eliminate communist sympathizers from their ranks. This idea had been building for a long time within various liberal and labor organizations, but Soviet-American difficulties provided the final rationale for such action. The albatross of communism was then publicly hung around the New Party's neck by other liberals anxious to disassociate themselves from such a taint. ${ }^{7}$ Finally, the Wallacites decided to take the third-party route precisely when the liberal-left felt its national standing to be most fragile. Thus the

6 The most accessible compendium of Wallace's views can be found in his Toward World Peace (New York: Reynal and Hitchcock, 1948). For the platform of the Progressive party see Peace, Freedom and Abundance (New York: Progressive Party, 1948).

7 Americans for Democratic Action, organized in early 1947 to provide a liberalleft alternative to the "united front" tactics of the Progressive Citizens of America, boasted openly in 1950 that it had done the "best job" on the reputedly communisttainted Progressive party. See the testimony of Francis Biddle in U.S. Congress, House Select Committee on Lobbying Activities, Lobbying, Direct and Indirect, VI, 81st Cong., 2nd Sess. (Washington: Government Printing Office, 1950), p. 12. 
idea of a third party that would further divide and weaken the liberal-labor electorate sent chilling shivers up the spines of established liberal-left politicians and their followers. In combination, these forces were enough to destroy the New Party.

President Truman's survival in the face of a double defection by the Wallacites and Dixiecrats in the 1948 election seems nothing short of miraculous even twenty years later. Surely in normal times such a division in the Democratic party would have earned it a resounding defeat. But these were not normal times. Hysteria was in the air, and the American voter turned to leadership that he knew and could understand. Harry S Truman was such a leader. But these election results do not make Wallace and the Progressive party any less interesting. The fact that they were able to get on the ballot in every state, that they had a vigorous national organization, that they persevered under one of the most vitriolic attacks in the history of American politics and, finally, that they had so many keen and sensitive minds among their members makes them a fascinating subject. Wallace himself was the most prophetic public figure in American life notwithstanding his tragic weaknesses as a politician and a statesman. ${ }^{8} \mathrm{He}$ and the New Party had much to say, and they put a prodigious amount of effort into saying it. Thus the Progressive party papers at The University of Iowa are important reading for anyone interested in liberal-left thinking and politics in the immediate post-war period.

This collection, in tandem with the papers of the Americans for Democratic Action at the University of Wisconsin, gives the Midwest a virtual monopoly over the most important sources dealing with the American liberal-left in the period. Much of the information on the Progressive party in the collection has been incorporated by its collector, Curtis MacDougall, a professor of journalism at Northwestern

8 Wallace's strengths were his very weaknesses. His overwhelming faith and often prophetic insight prevented him from realistically appraising given policy choices. Consider this poem attributed to him by one of his speech writers:

When the Phoney Liberals leave

Let no Progressive grieve

One new party must be made of two

When the Marshall Plan is dead and One World is just ahead

We'll all be brothers and no longer passing through.

Whether or not Wallace wrote this, it accurately portrays his often romantic faith. Lewis [Frank] to Curtis [MacDougall], undated, Progressive Party Papers, The University of Iowa. 
University, in his three-volume work Gideon's Army, already cited. ${ }^{9}$ But much interpretive work still needs to be done. Moreover, the collection is valuable for other reasons. First, MacDougall was what might be called a professional liberal. He associated himself with virtually every liberal cause of the period. Thus the collection is a gold mine of information on such groups as American Citizens for the Protection of the Foreign Born, Progressive Citizens of America, Independent Voters of Illinois, National Citizens Political Action Committee and the Independent Citizens Committee of the Arts, Sciences, and Professions, and so on.

A second interesting aspect of the collection is the number of important liberal-left individuals whose letters, statements and speeches are to be found in it. It has a massive collection of speeches by Henry A. Wallace, but, in addition, material may be found on other important members of the party: Glen Taylor, Elmer Benson, Calvin B. Baldwin, W. E. B. DuBois, Jess Gitt, Paul Robeson, Louis Adamic, John J. Abt and Vito Marcantonio.

Against the sweep of American history the Progressive party may not loom large. But it can provide valuable insights into the post-war thinking of significant liberal-left individuals and groups, if only to delineate policy alternatives that might have been available to American policy-makers in this period had they been able to rethink their own assumptions. The search for "what might have been" is often purposeless, but without it we find ourselves bound to a sort of historical preordination. Post-war policy decisions were in reality choices, and they cannot be understood in isolation from the swirl of ideas around them even if many of these ideas did not influence the political mainstream at the time. In addition, the experience of the New Party suggests what direct participation in the political process can do to the presentation and reception of new ideas. In the case of the Wallace party this participation destroyed their usefulness as a conveyor of unorthodox ideas.

9 This large collection includes such diverse items as scrapbooks, correspondence, posters, leaflets, speeches of various party officials and supporters, bills, receipts, tax and bank statements, press releases, newspaper clippings, telegrams, bulletins, party publications, form letters, campaign songs, photographs, petitions, nomination papers, memoranda and broadsides. A good deal of the correspondence concerns the various state organizations of the Progressive party (Texas, Vermont, California, Pennsylvania and Wisconsin are particularly well represented). Interesting and valuable items such as a copy of The Campaign Handbook, a 273-page explanation of the Progressive party's position on various issues, non-commercial recordings of public addresses by Henry A. Wallace and his 1948 running mate, Senator Glen H. Taylor, the Progressive party name list and the minutes of the Progressive party convention in 1948 are included in the collection. 


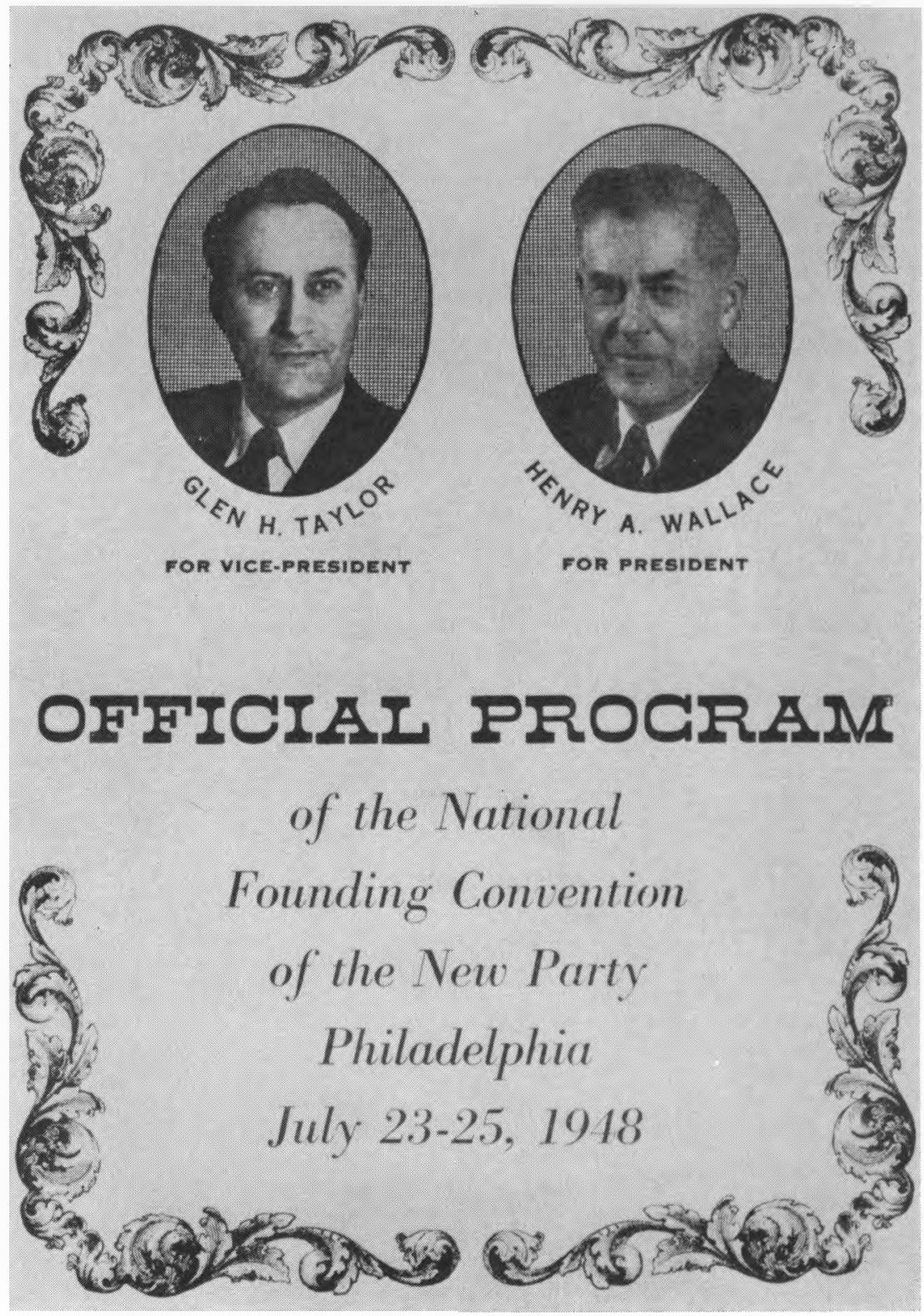

Among the many broadsides, pamphlets, press releases, speeches, notes and other records in the Library's collection of Progressive party papers is this program of the founding convention in 1948. 